the implementation of evidence-based preventive interventions. More legislative measures are needed to control and reschedule some prescription and over-the-counter medications. Treatment and rehabilitation services should be readily available and easily accessible to affected individuals. Working towards a national drug strategy and raising funds for training and research are of paramount importance.

\section{References}

AbdulRahim F. A. \& Al Shiekh A. (2012) Substance abuse and homelessness: mass methanol poisoning in Khartoum. Sudan Medical Journal, 48(1), 1-6.

El Tayeb M. T. (2004) Elindayah. Dar Azza Publishing and Distribution.

General Directorate of Narcotics Control (2014) Annual Drug Related Crime Report. MOI.

Ibnauf A. (2016) Alcohol and substance use among Sudanese medical students: a cross-sectional study. A paper presented at the 6th International Psychiatric Conference, 7-10 Oct. 2016, Khartoum, Sudan.
National Institutes of Health (2008) Principles of Drug Addiction Treatment: A Research-Based Guide, 3rd edn, p. 12. NIH.

Omer A. (2016) Profile and characteristics of the first 100 patients attended Hayat centre for psychosocial treatment and rehabilitation. A paper presented at the 6th International Psychiatric Conference, 7-10 Oct. 2016, Khartoum, Sudan.

Tarig O., Victor C., Abdulmoneim A., et al (2016) Epidemiology of substance use among university students in Sudan. Journal of Addiction, 2016(8), 2476164.

Tesfaye G., Derese A. \& Hambisa M. T. (2014) Substance use and associated factors among university students in Ethiopia: a cross-sectional study. Journal of Addiction, 2014(8), 969837.

United Nations International Drug Control Programme (1993) Alternative Development as an Instrument of Drug Abuse Control, Technical Information Paper, No. 5. UN.

United Nations Office on Drugs and Crime (2013) International Standards on Drug Use Prevention. UN.

World Health Organization (2012) Atlas: Substance Use in the Eastern Mediterranean Region. WHO.

\section{GLOBAL ECHOES} PAPER

\title{
A fish out of water: experience of working with the Māori people in New Zealand
}

\author{
Rebecca Chubb
}

Specialty Doctor in Old Age Psychiatry, North Staffordshire Combined Healthcare Trust; email rebecca.chubb1@combined. co.uk

\section{Conflicts of interest. None}

doi:10.1192/bji.2017.38

(c) The Author 2018. This is an Open Access article, distributed under the terms of the Creative Commons Attribution-

NonCommercial-NoDerivatives

NonCommercial-NoDerivatives
licence (http://creativecommons org/licenses/by-nc-nd/4.0/), which permits non-commercial re-use, distribution, and reproduction in any medium, provided the original work is unaltered and is ginal work is unaltered and is properly cited. The written permission of Cambridge University Press must be obtained for commercial re-use or in order to create a derivative work.
Experiencing life and work in an alien culture initially just felt unsettling, but it also really challenged how I perceived myself and my abilities as a doctor. Being the outsider in a group has the ability to hold an uncomfortable and scrutinising mirror up to yourself. It also offers a unique opportunity to reconsider the skills, attributes and knowledge needed to be a psychiatrist. As psychiatrists, we intellectually know that culture is integral to a personâs well-being and the care we deliver will never be truly holistic until we encompass that. However, it was only when I was the fish out of water that I truly began to appreciate its significance.

I had never felt embarrassed of being White before, but when I was in a meeting room on a forensic psychiatric unit on North Island, New Zealand, I was suddenly a very embarrassed White, British fish out of water.

The team, of which I was a member, was there to meet with the family of a Māori (the indigenous people of New Zealand) patient. As the family members walked in, they approached each of the team in turn and kissed us on the cheek. My shoulders rose towards my ears as they approached me and I could feel my stiff upper lip growing. I was every stereotype of a British person you can imagine rolled into one. Except for shaking hands (and I generally avoid that), bodily contact was not something I deemed appropriate in my line of work. I was a psychiatry trainee after all. Everybody else, including my British consultant, followed suit so... when in Rome.

The meeting opened with the social worker saying a karakia (prayer) and then a waiata (song in the Māori language). I was wholly unprepared for this; I tried to look respectful but was clearly completely ignorant. The meeting broached some very tricky topics but overall it went smoothly and ended with a further karakia. I was so ashamed that I could not participate in the customs or understand what was needed from me, something which usually I would have taken for granted. I could not pronounce their names or even begin to understand the significance of the prayers. I felt a desire to apologise for my ancestors, their colonisation and shout that I was not like that. I wanted them to see past my white face and West Midlands tone. On returning to my desk I enrolled in a Māori language course and cultural awareness day. I had of course worked with many different ethnic 
minority groups in the UK, but the feeling of complete impotence and cultural ignorance in that meeting stuck with me.

I felt what many of my Māori patients must feel in health services: lost and not fully understood. The health system was not made for - or by the Māori; it was devised by Europeans, with European values and priorities, but with the expectation that all New Zealanders will slot in neatly.

The long-reaching effects of colonisation are still being felt and play out in everyday healthcare. One ramification of colonisation is the very real and deliberate attempts of prior generations to eradicate Māori culture. For example, it is only the generation of current Māori grandparents who were punished in schools for speaking Te Reo Māori (Māori language).

Any healthcare service that does not embrace the culture of the people they are serving will always be inadequate. The health statistics for Māori unfortunately reflect this. A non-Māori New Zealander is expected to live, on average, 7 years longer than somebody of Māori descent. Virtually all health indicators are worse for Māori people in comparison with non-Māori people. Rates of alcohol and substance misuse, mental health diagnoses, domestic violence and suicide are all significantly higher amongst Māori. The suicide rate for a Māori male is 21.1 (per 100000 deaths) compared to only 14.6 for a non-Māori male (http://archive.stats.govt.nz/browse for_stats/ snapshots-of-nz/nz-social-indicators/Home/Health/ suicide.aspx). The prison population consists of a disproportionate number of Māori: over $50 \%$ (Department of Corrections, 2016). This is despite the fact that the Māori ethnic group made up $15.4 \%$ of the national estimated resident population in 2016 (MacPherson, 2017).

In psychiatry, we not only need to be able to communicate about illness, we need to connect, build rapport, empathise, engage and understand. Taking culture into account has made some big changes to what appear to be simple issues. For example, Māori creation stories and family histories are traditionally passed down orally and not in written form. This means that Māori culture tends to place greater importance on face-to-face communication than written communication (unlike Western culture), which often makes a phone call about an appointment more successful (in terms of attendance) than a written clinic letter.

I have witnessed a number of changes since I first went to New Zealand as a medical student in 2005. There is a tangible recognition of the Māori language; for example, television presenters pronounce Māori place names correctly (Taupō pronounced 'toe-paw' rather than the intuitive European way of 'taw-po'). Māori words have crept into the everyday language of all New
Zealanders. Language carries more than just words, it carries culture, beliefs and traditions, and its loss can be wide reaching. However, between 2001 and 2013, the proportion of Māori who reported they could hold an everyday conversation in the Māori language decreased from $25.15 \%$ to $21.31 \%$. Overall, this leaves only $3.73 \%$ of New Zealanders able to converse in Te Reo Māori (http://archive.stats.govt.nz/browse_for_stats/ snapshots-of-nz/nz-progress-indicators/home/social/ speakers-of-te-reo-maori.aspx).

I also found my notion of equality challenged: in the past I have been proud of my left-wing, open-minded stance but have to admit that I stood corrected on this occasion. My notion of equality is that everyone - regardless of race, creed and background - should have the same access to education and health services. But what if this service did not share the same health beliefs as me? What if the people attending that educational facility did not look like me? What if I had grown up without any role models following that road? Is that truly having the same access?

Equality should be measured by outcome, i.e. roughly the same number of Māori and non-Māori attending university, not simply by availability. When I put this view across to some of my European New Zealand friends, they argued that if Māori choose not to attend university then that was their choice. But it is what that 'choice' is based on that matters. I put it to them that if their daughter was attending a school where year after year the boys were performing better, going on to better jobs and opportunities, would they accept that or would they challenge whether the school is tailoring its education well enough towards girls? Would they not think that the school may need to rethink how girls learn, how to engage them so that they went on to university at similar rates to the boys? The same argument can be applied to the delivery of healthcare or access to university education among Māori.

As psychiatrists, we know that culture is integral to a person's well-being and the care we deliver will never be truly holistic until we encompass that. However, it was only when I was the fish out of water that I truly began to appreciate its significance.

\section{References}

Department of Corrections (2016) Prison facts and statistics December 2016. Department of Corrections. Available at http://www. corrections.govt.nz/resources/research_and_statistics/ quarterly_prison_statistics/prison_stats_december_2016. html\#ethnicity (accessed 11 January 2018).

MacPherson L. (2017) Māori Population Estimates: Mean year ended 31 December 2016 - tables. Statistics New Zealand. Available at http://www.stats.govt.nz/browse_for_stats/population/estimates_and_ projections/MaoriPopulationEstimates_HOTPMYe31Dec16.aspx (accessed 11 January 2018). 